\title{
РЕЖИМ КОНФИДЕНЦИАЛЬНОСТИ ИНФОРМАЦИИ ПРИ ОСУЩЕСТВЛЕНИИ КОММЕРЧЕСКОЙ ИЛИ ИНОЙ ТАЙНЫ
}

\author{
(c) 2019 Малышев Сергей Яковлевич \\ кандидат юридических наук, доцент, \\ доцент кафедры финансов, денежного обращения и экономической безопасности \\ Уфимский государственный авиационный технический университет, Россия, Уфа \\ Email:malyss5@yandex.ru
}

Статья направлена на освещение вопросов об обеспечении режима конфиденциальности информации при осуществлении коммерческой или иной тайны, исследуется содержание условий гласности и конфиденциальности (негласности), рассматриваются принципы конфиденциальности (негласности).

Ключевые слова: режим конфиденциальности информации, условия гласности, условия конфиденциальности (негласности), критерий.

Важно отметить, что, как в историческом прошлом, так и в настоящем времени, успех, благополучие и безопасность отдельных лиц, организаций (фирм), государства и в целом общества во многом зависят от желания, возможностей и умений хранить указанными субъектами определенных тайн (коммерческих, семейных, банковских, служебных, государственных и т.д.). На сегодняшний день в реальной действительности существует много различных видов тайн (государственная, коммерческая, адвокатская, медицинская и др.), однако все их объединяет одно обстоятельство - эти тайны могут возникать и существовать только при осуществлении режима конфиденциальности информации, т.е. в условиях конфиденциальности (негласности). Следовательно, в условиях гласности коммерческая или иная какая-либо тайна возникнуть и существовать не может. В связи с этим, справедливо возникает вопрос о разграничении условий конфиденциальности (негласности) от условий гласности. Что является критерием в определении условий гласности и условий конфиденциальности (негласности)?

Данный вопрос не является праздным, от ответа на него зависит понимание объективного и необходимого характера причинно-следственных связей, характеризующих условия гласности и конфиденциальности (негласности), т.е. закономерностей, которые присущи этим условиям. В настоящее время из-за принятия ложных критериев в определении условий гласности и конфиденциальности (негласности) со стороны отдельных ученых правоведов и практических сотрудников определенных служб и подразделений (например, службы безопасности, оперативных подразделений ОВД, следственных органов и др.), порой происходит подмена одного понятия другим, что негативно влияет на конечный результат их научной или практической деятельности. Перед началом исследования закономерностей, характеризующих условия гласности и конфиденциальности (негласности), обратимся к рассмотрению практического примера из жизнедеятельности некой компании (фирмы).

Руководитель компании (фирмы) встретился в служебном кабинете со своим сотрудником для обсуждения вопроса, касающегося сведений, имеющих важную коммерческую ценность для фирмы и к которым проявляют большой интерес конкуренты.

Возникает вопрос: в каких условиях гласности или конфиденциальности (негласности) осуществлена беседа руководителя фирмы со своим сотрудником?

Ответить однозначно на данный вопрос не представляется возможным, так как для нас еще не определен критерий условий гласности и конфиденциальности (негласности). По здравой логике рассматриваемая нами беседа руководителя фирмы со своим сотрудником на такие темы должна проходить в условиях конфиденциальности (негласности). Однако из анализа сложившейся ситуации не ясно какие обстоятельства указывают на то, что эта беседа проходит в условиях конфиденциальности (негласности), а не в условиях гласности. Дело в том, что сама по себе характеристика содержательной стороны темы 
беседы руководителя фирмы со своим сотрудником не является основанием «автоматически» считать такие условия беседы конфиденциальными (негласными).

Таким образом, если кто-либо из потенциальных оппонентов определит указанные выше условия как конфиденциальные (негласные), мы со своей стороны со всем основанием можем говорить о их гласном характере. Однако, если эти условия будут определены как гласные, мы со всей ответственностью скажем, что они конфиденциальные (негласные). Следует обратить внимание на то, что с внешней формальной стороны дела эта встреча руководителя компании со своим сотрудником, которая указана в нашем практическом примере, может проходить как в условиях гласности, так и в условиях конфиденциальности (негласности), так как мы в этом примере преднамеренно не раскрыли содержательную сторону данного мероприятия (встречи). Перед нами со всей очевидностью вновь встает вопрос об избрании критерия в определении условий гласности и конфиденциальности (негласности).

Под условиями гласности следует понимать условия, при которых заинтересованный в них субъект сознательно не применяет меры конфиденциальности (негласности) для сохранения в тайне от посторонних третьих лиц содержание (сущность) проводимых и (или) проведенных мероприятий (действий), в том числе и полученный, благодаря им, результат. В связи с этим посторонние третьи лица знают или потенциально могут знать о содержании (сущности) проводимых и (или) проведенных мероприятиях (действиях), а также полученный, благодаря им, результат.

В данном случае следует объяснить, почему посторонние третьи лица в условиях гласности потенциально могут знать о содержании (сущности) проводимых и (или) проведенных мероприятиях (действиях), а также полученный, благодаря им, результат. Дело в том, что если эти посторонние третьи лица со своей стороны предпримут какие-либо волевые усилия на то, чтобы узнать содержание (сущность) проводимых и (или) проведенных мероприятий (действий), то это сделать им удастся, так как заинтересованный субъект сознательно не принял меры конфиденциальности (негласности) для сохранения тайны. Важно отметить, что условия гласности могут быть двух видов:
- широкая (массовая) гласность - когда субъект заинтересован в распространении определенной информации среди широкой массы людей (например, проведение фирмой рекламной компании в отношении какой-либо продукции, товара; обращение правоохранительных органов к гражданам для оказании помощи в розыске преступников или без вести пропавших лиц и т.п.);

- узкая (потенциальная) гласность - когда у субъекта (руководителя компании, сотрудника правоохранительных органов) нет заинтересованности в сохранении в тайне определенной информации и широком ее распространении среди массы людей. Однако у третьих лиц при данных условиях гласности возникает потенциальная возможность узнать об этой информации, если только они для этого предпримут со своей стороны какие-либо волевые усилия.

Для наглядности обратимся к нашему практическому примеру, где руководитель компании обсуждает со своим сотрудником вопрос, касающийся сведений, имеющих важную коммерческую ценность для фирмы и к которым проявляют большой интерес конкуренты. Так, если этот разговор проходил в условиях гласности, то любой коллега по работе того сотрудника, который являлся указанным собеседником руководителя компании, может подойти к нему и спросить о содержании состоявшейся беседы и получить от него интересующую информацию. В данной ситуации потенциальная возможность третьих лиц знать интересующую их информацию реализуется в действительности благодаря тому, что со стороны заинтересованного субъекта (руководителя компании) сознательно не были предприняты меры конфиденциальности (негласности) для их сохранения в тайне.

Под условиями конфиденциальности (негласности) следует понимать условия, при которых заинтересованный в них субъект сознательно и своевременно применяет достаточное количество мер конфиденциальности (негласности) для сохранения в тайне от посторонних третьих лиц содержание (сущность) проводимых и (или) проведенных мероприятий (действий), в том числе и полученный благодаря им результат. В связи с этим посторонние третьи лица ни при каких обстоятельствах не должны знать о содержании (сущности) проводимых и (или) проведенных мероприятиях (действиях), в том числе и полученный благодаря им результат, 
за исключением случаев предусмотренных законодательством Российской Федерации.

Из анализа содержания вышеуказанных определений понятий условий гласности и конфиденциальности (негласности) видно, что критерием в определении этих условий является волевые усилия со стороны заинтересованного субъекта в сознательном применении или неприменении мер конфиденциальности (негласностu) для сохранения в тайне от посторонних третьих лиц содержание (сущность) проводимых и (или) проведенных мероприятий (действий), в том числе и полученный благодаря им результат. Таким образом, причиной условий гласности и конфиденциальности (негласности) являются волевые усилия заинтересованного субъекта по сознательному принятию или не принятию мер конфиденциальности (негласности) при создании определенных условий, а следствием выступают знания (или незнания) посторонних третьих лиц о содержании (сущности) проводимых и (или) проведенных мероприятий (действий), в том числе и полученный, благодаря им, результат.

В настоящее время среди ученых правоведов и практических сотрудников служб безопасности и правоохранительных органов, в вопросе об определении условий гласности и конфиденциальности (негласности) происходит подмена причинно-следственной связи, где в качестве причинной связи, явления рассматривают ее следствие.

При создании условий конфиденциальности (негласности) заинтересованный субъект (руководитель фирмы, сотрудники правоохранительных органов или специальных подразделений) должен руководствоваться в своих действиях принципами своевременности и достаточности принятия мер конфиденциальности (негласности).

Под принципом своевременности создания условий конфиденциальности (негласности) следует понимать необходимые действия заинтересованного субъекта по сознательному принятию в нужный момент достаточного количества мер конфиденциальности (негласности) для сохранения в тайне от посторонних третьих лиц содержание (сущность) проводимых и (или) проведенных мероприятий (действий), в том числе и полученный, благодаря им, результат.

Несвоевременность таких действий со стороны заинтересованных субъектов (руководи- теля фирмы, сотрудников правоохранительных органов или специальных подразделений) может привести к негативным последствиям, т.е. информация, как правило, в дальнейшем не сможет приобрести статус конфиденциальности (тайны), так как наступят условия ее разглашения. Для того, чтобы информация (например, о тактике негласных оперативно-розыскных мероприятий проведенных сотрудниками оперативных подразделений или определенных действиях конфиденциального характера со стороны руководителя фирмы) приобрела статус конфиденциальности (тайны), следует со стороны заинтересованных субъектов превентивное, предупредительное применение достаточного количества мер конфиденциальности (негласности) для создания необходимых условий в целях защиты такого рода информации от посторонних лиц.

Для наглядности обратимся к нашему практическому примеру, где руководитель компании обязан был заблаговременно создать условия конфиденциальности (негласности) перед началом беседы со своим сотрудником на интересующую его тему, представляющую важную коммерческую ценность для фирмы и к которой проявляют большой интерес конкуренты. Первоначальные меры конфиденциальности (негласности), принимаемые руководителем компании на начальной стадии создания необходимых условий, могут отличаться своей простотой и небольшой затратностью средств. Так, руководитель компании обязан позаботится о следующих обстоятельствах, имеющих превентивное, предупредительное значение:

- при беседе с сотрудником на интересующую тему не могут находиться в кабинете посторонние третьи лица;

- условия, в которых проходит беседа руководителя компании и его сотрудника, не должны позволять посторонним третьим лицам прослушивать их, в том числе и с использованием специальных технических средств;

- сотрудник должен быть предупрежден о неразглашении соответствующих сведений, ставших ему известными и (или) обладать определенным допуском к конфиденциальной информации;

- полученную конфиденциальную информацию руководитель компании в максимально короткий срок обязан задокументировать на материальный носитель с грифом ограничения 
доступа (например, «Коммерческая тайна», с указанием обладателя такой информации);

- осуществить регистрацию и учет конфиденциальной информации;

- в дальнейшем со стороны руководителя компании в отношении полученной конфиденциальной информации применяются последуюцие меры конфиденциальности (негласности), которые предполагают установления в полном объеме режима коммерческой тайны в соответствии со статьей 10 Федерального закона «О коммерческой тайне» [1].

В части 1 статьи 10 Федерального закона «О коммерческой тайне» указаны меры по охране конфиденциальности информации, которые определяют условия конфиденциальности (негласности), создаваемые в целях защиты коммерческой тайны. Следует отметить, что первоначальные и последующие меры конфиденциальности (негласности) на законодательном уровне определены частью 1 статьи 10 настоящего Федерального закона. Отличие этих мер конфиденциальности (негласности) состоит в том, что первоначальные меры имеют превентивное, предупредительное значение и применяются на начальном этапе установления режима конфиденциальности информации, а последующие меры - на конечном этапе установления режима конфиденциальности информации, т.е. установления режима коммерческой тайны.

Если вышеуказанные первоначальные меры конфиденциальности (негласности) превентивного, предупредительного характера не будут приняты со стороны руководителя компании, то возникает реальная угроза разглашения этой ценной информации и дальнейшее установление в отношении ее режима коммерческой тайны будет несвоевременной, неэффективной или вовсе бесполезной, так как она может приобрести признаки общедоступности и известности.

Важно отметить, что первоначальные и последующие меры конфиденциальности (негласности), которые применяет субъект для создания указанных условий в целях защиты конфиденциальной информации (тайны), должны отвечать принципу достаточности их принятия.

Под принципом достаточности принятия мер конфиденциальности (негласности) при создании интересующих нас условий следует понимать принятие таких мер со стороны заинтересованного субъекта, которые по своим количественным и качественным характеристи- кам полностью удовлетворяли бы потребность в создании необходимых условий конфиденциальности (негласности) в целях сохранения информации в тайне и ее защите от посторонних третьих лиц.

При недостаточности принятия мер конфиденциальности (негласности) со стороны заинтересованного субъекта неизбежно наступают негативные условия разглашения (рассекречивания, расшифровки) тайны.

Таким образом, в юридической и правоохранительной практике следует различать следующие виды условий, при которых конкретная информация о чем-либо приобретает свой определенный правовой статус, имеющий открытый или конфиденциальный характер:

- условия гласности, при которых информация может потенциально приобрести или приобретает открытый и (или) общедоступный, известный характер;

- условия конфиденциальности (негласности), при которых информация приобретает правовой статус тайны;

- условия разглашения (рассекречивания, расшифровки) тайны, при которых у конфиденциальной (негласной) информации по мимо воли ее обладателя нарушается правовой статус тайны и приобретается негативный открытый характер, так как становится известна посторонним третьим лицам.

Принцип достаточности применения мер конфиденциальности (негласности) основывается на знании и постоянном изучении субъектом (руководителем компании, сотрудником правоохранительных органов) возможностей противоположной стороны (конкурентов, преступной среды) по преодолению установленных в целях сохранения конфиденциальной информации в тайне защитных мер, в том числе с использованием специальных технических средств. Таким образом, субъекты конфиденциальной информации для организации и обеспечения системы безопасности (например, экономической, общественной, государственной) обязаны постоянно осуществлять мониторинг состояния внешних и внутренних угроз указанной системе с тем, чтобы адекватно и соразмерно отвечать на вызовы противной стороны. Важно понимать, что нарушение принципа достаточности применения мер конфиденциальности (негласности) неизбежно приводит к разглашению (рассекречиванию, расшифровке) тайны (коммерческой, банковской, государственной и т.п.). 


\section{Библиографический список}

1. Федеральный закон от 29 июля 2004 г. № 98-Ф3 «О коммерческой тайне» // Собрание законодательства РФ. 2004. № 32. Ст. 3283. 